\title{
LIMITES, FISSURAS, PRAZER E RISCO EM FESTAS DE ORGIA PARA HOMENS
}

\author{
Victor Hugo de Souza Barreto ${ }^{1}$ \\ ${ }^{1}$ Universidade Federal do Rio de Janeiro, Rio de Janeiro, RJ, Brasil
}

\section{Apresentação}

Neste artigo apresento algumas das conclusões obtidas durante o trabalho de campo para a realização de minha tese de doutorado em antropologia. ${ }^{1}$ Ali empreendi uma análise sobre a prática do sexo grupal/coletivo realizada entre homens em reuniões ou eventos de orgia. Mais especificamente, uma etnografia de festas de orgia entre homens que acontecem na cidade do Rio de Janeiro.

O desenvolvimento deste trabalho se deu em função do acompanhamento durante dois anos e meio (do início de 2013 à metade de 2015) de quatro dessas festas de orgia que acontecem periodicamente na cidade. Elas são organizadas uma ou duas vezes ao mês, uma delas semanalmente, em diferentes locais da cidade carioca, seja em clubes, saunas, apartamentos comerciais, ou mesmo em um sítio ou em um barco. Dessas quatro festas, duas fazem parte do que eles chamam de "processo seletivo", isto é, uma escolha ou avaliação do público que pode entrar no evento. E as outras duas são abertas a quem quiser ir, desde que corresponda à exigência de ser homem (cisgênero) e a um determinado perfil de masculinidade desejado. $^{2} \mathrm{O}$ número de participantes varia muito, mas ficou em torno de 150 a 200 homens naqueles eventos que não exigiram seleção, e no máximo 50 naqueles em que houve o processo seletivo. ${ }^{3}$

Nessa pesquisa dediquei-me a analisar a multiplicidade em relação aos jogos e às práticas sexuais de tais eventos, buscando entender o que dizem os corpos que interagem no sexo coletivo e que utilizam essas festas como territórios existenciais para a efetuação de suas práticas e a realização de seus desejos. Considerei também, neste exercício etnográfico, os processos de construção da subjetividade dos atores e da micropolítica dos corpos gestada em tais contextos e cenários. A estratégia que adotei foi a de tentar mapear 
o campo através do elemento do desejo, tornando-o objeto e fio condutor da análise. O que proponho é me aproximar, portanto, de uma "antropologia do desejo" (Perlongher 1993; Rolnik 1989), já que, como dizia Deleuze,

O desejo é o sistema de signos a-significantes com os quais se produzem fluxos de inconsciente no campo social. Não há eclosão de desejo, seja qual for o lugar em que aconteça, pequena família ou escolinha de bairro, que não coloque em xeque as estruturas estabelecidas. O desejo é revolucionário, porque sempre quer mais conexões, mais agenciamentos (Deleuze \& Parnet 1998:53).

Desejo é entendido aqui como vontade, como algo que nos coloca em movimento, o que constitui nossos interesses pelas coisas e que encadeia nossos afetos. E é isso o que procuro aqui: o desejo como "processo de produção de universos psicossociais. O próprio movimento de produção desses universos" (Rolnik 1989:25), já que

Não existe sociedade que não seja feita de investimentos de desejo nesta ou naquela direção, com esta ou aquela estratégia e, reciprocamente, não existem investimentos de desejo que não sejam os próprios movimentos de atualização de um certo tipo de prática e discurso, ou seja, atualização de um certo tipo de sociedade (Rolnik 1989:58).

O analista social (ou o "cartógrafo", nos dizeres de Rolnik) precisa estar atento às estratégias do desejo em qualquer fenômeno da existência humana que se proponha a perscrutar: sejam "os movimentos sociais, formalizados ou não, as mutações da sensibilidade coletiva, a violência, a delinquência" (Rolnik 1989:58) ou, como principalmente no caso aqui, as práticas sexuais realizadas em festas de orgia.

A meu ver, há uma proposta nesses encontros sexuais coletivos que diz respeito a um determinado modo de existência relacionado a um desejo pela intensidade, por práticas, encontros e interações demarcadas por serem poderosas. No caso, a conformação de uma certa "estética da existência" (nos termos das obras finais de Foucault), baseada numa ética dos desejos e dos prazeres própria desses contextos. ${ }^{4}$ A "estética da existência", segundo Foucault, se relaciona a um exercício de invenção ou construção de si através das artes de viver, que

devem ser entendidas como as práticas racionais e voluntárias pelas quais os homens não apenas determinam para si mesmos regras de conduta, como também buscam transformar-se e modificar seu ser singular, e fazer de sua vida uma obra que seja portadora de certos valores estéticos e que corresponda a certos critérios de estilo (Foucault 2006:198-199). 
Uma "estética da existência" que, dessa forma, tem a intensidade como um dos principais critérios. Aproximo-me da leitura que Deleuze faz sobre o pensamento espinozista em que a intensidade é um dos elementos-chave na capacidade de afetação e sensibilidade dos corpos, já que é ela que força e que faz sentir, seja aumentando, seja diminuindo a potência de agir e existir, o que estes autores chamam de bons ou maus encontros (Barreto 2018c:164). Percebo que a busca pela intensidade que percorre as práticas observadas nesse contexto está em seu sentido de força, de sensibilidade, daquilo que é intenso, de levar o corpo a experimentar sensações e emoções, às vezes até extremas.

Dizer que as festas de orgia e seus participantes se perfazem por uma valorização do critério de intensidade e do intenso, não quer dizer que os critérios relativos à organização e à manutenção de suas vidas cotidianas, ao dia a dia e a uma concepção temporal relativa ao ordinário sejam desconsiderados, mas que constituam de fato nesses espaços um "tensor libidinal" (Perlongher 1987), ou seja, sua tensão estimula desejos, prazeres e mesmo perigos, como espero deixar claro ao longo deste artigo.

A busca por sensações ou experiências (principalmente físicas) cada vez mais intensas e a maneira como isto se relaciona com a nossa sexualidade, sensualidade e sensibilidade fazem parte de um movimento ocidental de construção de uma certa forma de hedonismo mapeada por Duarte (1999). Naquilo que o autor chama de uma contemporaneidade voltada para o "império dos sentidos" reside a tensão entre o "mundo extensivo" ${ }^{5}$ e a intensidade, que é perceptível nas ações mais cotidianas e, como pretendo demonstrar, é uma das características principais do cenário etnográfico em questão.

Trata-se da tensão entre a maximização da vida (através da totalidade da pessoa), que é um investimento no longo prazo e na duração, e a otimização do corpo (através da concentração no prazer), que é uma aposta no curto prazo e na intensidade. Essa é uma tensão muito vívida para diversos problemas centrais que enfrentamos como analistas sociais (Duarte 1999:28).

Dessa forma, os espaços comerciais dedicados a encontros sexuais coletivos são importantes na medida em que oferecem um terreno privilegiado para a investigação da produção social, tanto material quanto simbólica, dos sujeitos e dos corpos humanos, "bem como das concepções e das experiências de vida e de morte implicadas nessa produção" (Vargas 2001). Nesse sentido, o que a experiência (ou a experimentação) da sexualidade nessas festas coloca em jogo são outros modos de subjetivação e corporalização, modos propriamente intensos, como venho dizendo, em que 
o "se jogar" nos instantes de intensidade das interações sexuais possíveis nas festas é "se perder", "se (re)encontrar" e colocar os aspectos como trabalho, família, casa, saúde e todos os valores morais correspondentes a eles em outros termos, acionando ou fugindo de seus elementos estrategicamente a partir de seus desejos. ${ }^{6}$

Atentar para esses eventos intensos é aproximar-me de etnografias que já vêm trazendo um deslocamento de questões para a busca de um entendimento mais próximo daquele que as pessoas dão às práticas que realizam. Pesquisadores como Vargas (2001), Eugênio (2006), Ferreira (2006) e Rocha (2011) apontam como em diferentes contextos, como o do uso de drogas, das festas de música eletrônica, da prática de esportes radicais e das idas a boates, existem eventos que envolvem agenciamentos paradoxais de autoabandono que visam ao "sair de si", ao êxtase, ao descentramento, à conexão com uma alteridade (des)conhecida ou mesmo ao "encontro de si". ${ }^{7}$ Tomam a "onda", a "vibe", a "loucura" (assim como eu tomo aquilo que meus interlocutores chamam de "putaria"), como modos singulares de engajamento no mundo. "Tais descentramentos dizem respeito quer à 'razão', quer ao 'corpo' ou, melhor dizendo, a ambos simultaneamente" (Vargas 2001:215). Daí, o que parece estar em jogo nessas alterações de percepção é a produção de outras maneiras de produção da subjetividade ou de subjetivação dos corpos. ${ }^{8}$

Neste artigo privilegiarei a descrição densa das práticas intensas observadas em campo para que a partir dela possamos compreender certas experimentações eróticas nos "limites da sexualidade". Percebo haver nesses eventos o que Deleuze chama de "ética da potência" (Machado 2013:72), de práticas que se diferenciam pela quantidade de prazer ou êxtase que causam, e mesmo pela busca de uma intensidade (ou de um prazer) cada vez maior. Porém, é claro que a busca, a vontade de alcançar uma "enésima" potência, ao mesmo tempo em que pode se apresentar como força criadora, maneira de singularização e (por que não?) de extremo prazer, também tem um potencial destruidor, de risco, de aniquilação. São como os momentos de "fissura" conceituados por Díaz-Benítez como aqueles instantes de fronteira ou rompimento, nos quais as práticas (ainda que consentidas) "alcançam uma intensidade que não era possível prever ou antecipar" e "que rompe com o pacto empreendido com o outro e consigo mesmo, ocasionando emoções que evocam mais perigo do que prazer" (2014:1).

A questão que se coloca a todo tempo nas festas de orgia tem a ver justamente com esse manejamento dos limites, o controle de si e a imersão em êxtases, devires e estados de alta intensidade. Assim, o que se passa nesses espaços seriam acontecimentos em que determinadas práticas sexuais estariam na borda do que Gregori chama de "limites da sexualidade", que 
seria "a zona fronteiriça onde habitam norma e transgressão, consentimento e abuso, prazer e dor" (2010:3).

Eu caracterizei acima tais eventos e experiências, esse sair de si, como paradoxais também pelo fato de, em campo, ter observado uma "sobriedade", um autocontrole e um cálculo racional de meus interlocutores que eu não esperava encontrar em um evento como uma orgia e que não costumam ser descritos na literatura sobre rituais orgiásticos (Barreto 2017b). O que é posto a cada ida a um desses eventos é a repetição da irresistível "tensão libidinal", ou seja, de um desejo constante em que se embaralham o êxtase, o aumento e a perda do controle, em que os limites são questionados e há um risco ou perigo que pode aparecer a todo momento a depender da intensidade das interações.

É sobre a questão dos limites, suas "fissuras" e sua relação sempre tensa entre a "onda" (buscada e desejada) da "putaria" e o prazer na fronteira porosa com a dor, o perigo e os riscos que irei me ocupar nas próximas páginas a partir da apresentação dos dados produzidos no campo.

\section{Limites e fissuras}

A aproximação com a ideia de (des)controle poderia começar pela questão do uso de algumas substâncias como o álcool e outras drogas. De maneira geral, pouco presenciei o uso aberto de drogas (exceto poppers ${ }^{9}$ ) ou o consumo exagerado de bebidas alcoólicas durante as festas. Ao revelar surpresa para um dos meus interlocutores por não ter visto o consumo de álcool e drogas que esperava ver em um evento orgiástico, ele me respondeu: "As pessoas vão lá para curtir a putaria, se elas se entorpecerem não vão aproveitar. Quando eu estou ali fodendo, eu não quero que nada atrapalhe a minha percepção e sensação do que eu estou fazendo".

Com o tempo percebi que as bebidas são um recurso ou um aditivo usado principalmente por "principiantes": aqueles que estão indo pela primeira vez ou que ainda não se acostumaram com o ambiente das festas. Não costumam ser usadas pelos participantes mais frequentes. ${ }^{10}$ Acredito que isto aconteça não só pela socialização das regras locais, como também pela absorção do jogo da "putaria", em que é dito que o entorpecimento atrapalha mais do que ajuda. Para estes, "beber para se soltar" não é mais preciso ou necessário. Não há amarras a afrouxar, há os próprios limites a serem testados, como numa autocompetição mesmo, o que contribui para o discurso local que valoriza a figura de "homens machos". Pude acompanhar a "primeira vez" de um desses novatos: chegou olhando tudo meio assombrado e logo parou 
em um dos bares para beber um pouco. Foi bebendo, bebendo, se tornando inconveniente, sem conseguir se misturar nas interações. Tendo consciência disso, ele preferiu ir para a área dos armários sozinho para se recuperar. O organizador foi chamado e disse para ele: "então, eu vou falar para você fazer assim, sobe para o terraço e lá descansa um pouco, pega um pouco de ar, toma um refrigerante ou uma água e, quando você estiver melhor, volta". O rapaz subiu obedientemente. "Com gente sem noção, a gente faz assim: manda para o terraço beber água", disse o organizador, gerando risadas entre os presentes e comentários avulsos como "não sabe brincar", "não sabe beber", "se está assim com álcool, imagina se fossem drogas".

Em outra festa, percebi que se aglomeraram em um dos bares três homens de um grupo de amigos que também exageraram na bebida. Um mantinha a cabeça jogada para trás, claramente passando mal, enquanto outro vomitava sentado com uma lixeira presa entre as pernas, e o terceiro dormia estirado nu no sofá roncando bem alto. O organizador me explicou: "chegaram em galera, não estão acostumados com a festa... Eu costumo colocar logo pra fora quando fazem isso. Hoje tô de bom humor. Coloquei eles ali de castigo para não atrapalharem".

Sobre as substâncias utilizadas, o que pude encontrar abertamente durante o trabalho de campo foi o uso de Viagra ou Pramil ${ }^{11}$ e poppers que funcionam mais como aditivos sexuais para melhorar a performance do que para "dar onda" necessariamente. ${ }^{12}$ É claro que existe o uso de outras drogas nas festas. Os organizadores me disseram ser normal encontrar papelotes e pinos (cápsulas de plástico) de cocaína nos banheiros, e que também já tiveram que expulsar pessoas, fosse porque estivessem alcoolizadas, fosse porque ficaram agressivas sob o efeito de alguma substância, acabando por incomodar e atrapalhar as outras, ou ainda porque alguém da festa denunciou o uso. ${ }^{13}$

Durante a apresentação de show de sexo ao vivo que acontece no final de uma das festas, um dos organizadores usou o microfone para dar uma bronca nos participantes.

Eu não quero saber de gente se drogando na festa! Não permitimos isso! Você quer usar alguma coisa, usa fora daqui. Não quero saber de gente fumando maconha no terraço nem cheirando o caralho aqui... Quer dizer, cheirar caralho pode, vai cheirar um bom pau que já dá maior onda, vai cheirar cu também. Estamos entendidos?

E logo depois da fala, Ivan veio comentar comigo: "Ué, não pode fumar um (fumar maconha) lá em cima, não? Ih, bom saber, achei que podia, aliás sempre fumei aqui, é de lei, sempre tem gente lá fazendo isso. Devem ter 
caguetado, então...". Além de Ivan alguns poucos também comentaram sobre o uso de "MD", ${ }^{14}$ mas sempre de uma forma muito reservada. Ainda que o álcool e as drogas possam funcionar como catalisadores de uma "jogação", de uma intensidade ou de uma "onda" maior e mais potente na "putaria" das orgias, seu uso (ou excesso) não é bem visto, sendo mesmo proibido pelos organizadores desses eventos. O que parece haver, portanto, é um acordo implícito (mas não necessariamente respeitado) no controle do corpo quanto ao uso de substâncias. ${ }^{15}$

Como afirmei anteriormente, o controle de si e a imersão nesses estados de êxtase intenso constituem um jogo de tensão erótica que atravessa todas as festas e são alguns dos fatores de atração desses eventos. A fruição da "putaria" na orgia exige um mergulho, que algumas amarras sejam deixadas para trás e certos limites sejam ultrapassados, uma espécie de autoabandono e dissolução. O "acontecimento-limite" é a todo momento colocado à prova e pode atravessar diversas fronteiras: físicas, emocionais, sensoriais e subjetivas. Porém, como me alertou um dos interlocutores, "é preciso saber parar".

Igual agora há pouco. Estava ali no "aquário" (um quarto com paredes de vidro para observação) onde fui chupado por dois, mais dois nos meus peitos e um outro me beijando... suando muito num quarto quente, abafado e cheio de homem! Quando um desses que estava chupando se levantou, virou a bunda e queria que eu comesse ele. Cara, pra mim não dava mais. Agradeci, dei um beijinho e saí. Não era nem porque não estivesse curtindo, mas porque eu precisava de uma pausa, entende? Respirar um pouco, pegar um ar antes de algo mais forte. Até para sair dali foi tenso, um monte de gente junta e suada, escorregando, um monte de mão tentando me pegar, segurando meu pau. To meio tonto até agora, olha como estou, parece que acabei de fazer uma corrida! Não, é muito gostoso, mas chega uma hora que você precisa saber parar, dar uma pausa pra descansar.

O que ele está me dizendo é que é preciso, ou pelo menos mais "seguro", manter um certo controle e consciência de seus limites para que a intensidade não seja grande demais para você. Só que nem sempre se consegue fazer isso. Um dos shows que foram apresentados numa festa teve como tema a prática do gang bang: um dos participantes se apresentaria no show se autodesafiando a ser passivo com o número máximo de ativos que aguentasse. Era um rapaz branco, cabelo e barba rala pretos, mais ou menos em torno dos 25 anos, de altura baixa e corpo definido. Chegou ao 
palco com os atores usando óculos escuros e vestindo uns meiões pretos de renda fina e uma cueca que logo foi retirada para a interação com os dois atores no palco. Os óculos permaneceram até o final, mas as meias ficaram rasgadas em alguns pontos. Após ter atuado como passivo para os atores no palco, o organizador passou a incentivar a plateia para que viesse "comer o garoto também". Um tatame foi colocado no chão entre a plateia, que foi se aproximando aos poucos colocando o rapaz no centro do círculo. As luzes baixaram em pontos vermelhos e foi dito ao microfone: "o desafio do passivo começou! Vamos ver quanto ele aguenta!".

A cada um que se aproximava para penetrá-lo, o rapaz tinha o cuidado e a atenção de colocar a mão no pênis do outro para conferir se ele estava usando preservativo, mesmo que estivesse de costas, e só então permitia que o outro o penetrasse. A cena foi tomando uma intensidade grande, o rapaz já estava bastante suado e não paravam de se aproximar homens para se revezarem na penetração, para tocá-lo, para colocá-lo para chupar e aos poucos fui percebendo que o gesto verificador do preservativo já começava a ser esquecido, até o momento em que definitivamente não foi mais feito. O rapaz não mais conseguia, não lembrava, não queria ou mesmo deixou de se importar. Ele não conseguia se voltar para olhar quem o penetrava. Afastei-me da cena quando o número de penetrações já tinha chegado a 15 e, com o apagar das luzes, não conseguia acompanhar mais com atenção. Portanto, ainda que o rapaz tenha tido o cuidado e a preocupação inicial de conferir se aqueles que o penetravam estavam devidamente com camisinha, a intensidade da interação fez com que ele perdesse o limite do controle, mesmo permanecendo na interação.

A intensidade da efervescência também pode (se) romper com a questão da violência e com a dor. As "fissuras" são acontecimentos recorrentes nesses eventos. Tomemos como exemplo uma cena que presenciei em que um rapaz magro, louro, com uma aparência bem jovem, de um tipo físico que chamam aqui de twink $^{16}$ estava no centro de uma roda de cinco homens com um tipo físico e tamanho bem maiores do que os dele. A cena funcionava como uma encenação de "curra": o rapaz era meio que jogado de um para outro com uma certa violência, era puxado pelos cabelos para se abaixar e chupar um deles ou então para se dobrar e ser penetrado com movimentos fortes. Ouviam-se alguns tapas, cuspes e palavras de humilhação: o rapaz dizia "não, não, não..." sem muita força e com um certo sorriso no rosto, o que divertia e incentivava a roda a intensificar a interação. Até que em determinado momento ouviu-se um "Porra, me machucou!" vindo do rapaz, dito de maneira mais alta e em um tom diferente dos "nãos" anteriores. Imediatamente a cena cessou e todos ao seu redor ergueram a mão como num jogo de futebol 
em que é apitada uma falta. Algo feito ali tinha ultrapassado o limite de um jogo de dor prazerosa causando uma dor insuportável. Passou-se do limite do twink ou o rapaz extrapolou os seus limites. A "fissura" ocasionada por um ato que eu não consegui perceber qual foi quebrou o pacto da cena, dando um fim a ela, e o rapaz saiu da roda, empurrando alguns em seu caminho, claramente aborrecido e desfazendo a aglomeração que tinha se formado.

Outro exemplo foi quando, no dark room (quarto escuro) de uma das festas, reparei em um casal que se agarrava numa interação um pouco agressiva. O que atuava como ativo naquele momento colocava o outro para chupá-lo com força, fazia com que ele engasgasse de propósito e dava tapas no rosto e na bunda do parceiro. Este parecia gostar e estimulava pedindo mais e com mais força. Até que, ao levantar, começou a distribuir mordidas pelo corpo do ativo, que foi deixando a princípio, mesmo que suas feições demonstrassem uma certa dor, mas quando chegou na área do pescoço, empurrou o outro com certa força: "para, no pescoço não!". O limite aqui foi alcançado não só pela dor, mas também pela possibilidade de que uma marca no pescoço revelasse algo que o ativo não desejasse. Após essa quebra, a interação não voltou mais a funcionar direito, o ativo brochou e logo se afastou do parceiro. Vi os dois retomando a interação minutos depois, mas claramente não era a mesma empolgação e de novo não durou muito, mesmo com um certo esforço do outro.

O que é insuportável não é o mesmo para cada um, nem a mesma coisa em todas as interações. Varia com a intensidade da efervescência dos encontros, com a disposição de cada um e com o "talento" de alguns indivíduos em saber manipular os limites, os seus e os dos outros. A ideia de "talento" acionada por meus interlocutores se aproxima da categoria de skills de Ingold (2000), no sentido de que, ainda que dispute um certo espaço entre o inato e o adquirido, se perfaz na prática em um determinado contexto relacional e como forma de singularização dos indivíduos. Na capacidade de causar intensidade ou efeito em si e/ou no outro se encontram as técnicas pessoais adquiridas nas experiências intensas. As práticas nesses eventos são poderosas no sentido de que são feitas para causar emoção, afetações, experimentações que proporcionem uma "ressonância carnal" (Paasonen 2011). A violência cumpre um papel importante ao compor os desejos dos participantes. ${ }^{17}$ Nesses eventos, a violência é um elemento potente que, ao ser acionado nas práticas realizadas, demonstra uma capacidade erótica em potencializar sua intensidade. ${ }^{18}$

O dispositivo que se convencionou como principal critério para a separação entre o ato permitido e o abusivo (ou mesmo como legal e legítimo) é o "consentimento" - elemento que se tornou fundamental como ferramenta de 
legitimação de determinadas práticas sexuais como o BDSM, ${ }^{19}$ por exemplo (Zilli 2009; Díaz-Benítez 2012; Facchini \& Rossetti 2013); daí a sigla que se convencionou chamar SSC (são, seguro e consentido). Nele não haveria nenhum tipo de abuso ou violência sexual, já que se trataria de práticas seguras das quais todos participam conscientes e consensualmente. Só que, como problematiza Lowenkron, a ideia de consentimento é herdada de um determinado paradigma liberal, "nos princípios de livre disposição de si e autonomia da vontade do sujeito racional responsável e senhor de si [...] no ideal individualista moderno" (2013:35). A própria autora mostra como a categoria "polissêmica e escorregadia" de "vulnerabilidade" é capaz de dissolver o valor atribuído ao consentimento (2013). Essa "autonomia da vontade" é relativizada pelo fato de que nem todos têm a capacidade ou estão numa mesma posição de vantagem em que o poder de consentir, de fazer escolhas ou, enfim, de ter agência seja dado de forma igualitária.

Não se pode fechar os olhos para o fato de que muito da erotização do outro nesses eventos de orgia implica ou depende de uma diferença que encobriria determinadas desigualdades. As questões raciais, principalmente, são reveladoras disto, como apontei em outros textos (Barreto 2017c, 2019), mas há recortes e fatores que interseccionam e atravessam as relações a partir de alguns jogos de poder. ${ }^{20}$ Muitos dos desejos que são percebidos nessas festas revelam que diferenças, tais como gênero, idade, classe/status e cor/raça, que, em certas situações, operam no plano do abuso também podem operar no plano do prazer. Como aponta Gregori (2010), trata-se de um desejo por aquilo que tensiona as diferenças, as hierarquias e algumas posições sociais. Como mostrei acima, esse jogo erótico de tensão pode se romper nas "fissuras" que invariavelmente acontecem durante as interações. Mas o que se percebe é que até elas precisam ser silenciadas para que uma determinada construção de masculinidade, que é desejada nesses espaços, e certos "roteiros de gênero" (Gagnon 2006) não se desestabilizem. ${ }^{21}$ Afinal, um "macho" tem que saber aguentar e ter disposição numa "putaria". Ficar reclamando que está doendo, fugir do desafio, não "aguentar a pressão" mostram uma fragilidade ou uma vulnerabilidade que não combina com os princípios de um tipo de orgia em que "vale tudo" numa "putaria entre machos".

\section{Prazer e risco}

Para além da relação entre prazer e violência nesses eventos, que pode tornar a fronteira entre o prazer e o abuso um pouco nebulosa, outro ponto importante é sobre o prazer e o risco, principalmente naquilo que se refere 
ao cuidado com as doenças e à contaminação. "Se jogar" na "putaria" é, de certa forma, um "empreendimento de risco", tal como conceitua Gregori, um evento no qual "o risco à integridade física e moral das pessoas é uma possibilidade aberta e não dada de antemão" (2010:4), em que a própria ideia de perigo imprevisível torna-se atrativa e com alto potencial erótico.

Não foram poucas as vezes em que pude observar pessoas interagindo sem camisinha ou em que ouvi comentários dos participantes como: "as pessoas aqui são muito loucas, todo mundo transando sem camisinha! Porra, não é porque você tá numa putaria que precisa fazer isso. Nem é só pela Aids, é por um monte de coisa, pela sujeira mesmo, vai ficar enfiando o pau em qualquer cu?". Transar sem o preservativo não seria uma ação motivada pela sua falta, já que em todas as festas que acompanhei tanto camisinhas quanto gel lubrificante foram distribuídos, ou então espalhados pelos espaços em grande quantidade.

Cara, a gente costuma receber uma certa quantidade do Ministério da Saúde ou de alguma ONG e eu ainda faço questão de comprar mais com dinheiro do meu próprio bolso. Mas vou te dizer, do que eu vejo acontecendo nas minhas festas e do que sobra de camisinha no final, só uns 30\% devem usar mesmo. Claro que tem aqueles que já trazem camisinha e gel de casa, já vêm preparados, gostam de um determinado tipo ou marca e tal. As que eu tenho são aquelas de posto, pessoal reclama... Mas mesmo assim, eu vejo porque sou eu que ajudo a limpar tudo no final, né? (organizador)

Ou como me resumiu outro organizador: "não sou fiscal de foda de ninguém, sei que tem bareback (sexo sem camisinha), mas meu papel eu faço, forneço o kit-foda". Segundo os organizadores, portanto, seria da responsabilidade de cada um o cuidado de si mesmo, pois não são "babás de homem grande", "até porque todo mundo sabe que vários soropositivos frequentam a festa". Ser soropositivo aqui é muito mais uma categoria de acusação (principalmente daqueles que "se jogam" mais) do que uma condição que seja assumida de forma aberta e pública. Mas, certa vez, presenciei uma exceção: numa roda de conversa com uns dez homens na área dos armários ao final de uma festa em que o tema debatido era a distribuição da PrEP 22 pelo Sistema Único de Saúde (SUS), um dos presentes se pronunciou: "eu acho ótimo! Principalmente para mim que sou soropositivo". A informação foi recebida com um silêncio constrangedor, mas que ele continuou: "mais alguém aqui é? (novo silêncio) Claro que tem mais, só que ninguém tem coragem pra falar isso, né?". ${ }^{23}$

Um dos fatores práticos para se deixar o preservativo de lado me foi apontado por um participante: "como é que eu vou carregar camisinha e gel 
pelado desse jeito? A galera aqui guarda dentro da cueca ou então colocam dentro da meia, até já vi gente com uma bolsinha pendurada no pescoço tipo aquelas pra carregar documento e dinheiro no Carnaval, sabe? Acho desconfortável".

Imagina, você está naquela coisa intensa no banheiro que fica em uma das pontas da sauna. Aí, para pegar camisinha, você tem que ir lá na recepção que fica lá do outro lado da sauna. Você vai conseguir interromper, pausar, descer até o seu armário ou então na recepção, pegar os apetrechos, voltar e continuar de onde parou? Ou então pensando que você tá no meio de uma galera como é aqui. Não tem como... Você consegue?

Para além de uma "dificuldade logística" e da interrupção da intensidade do momento da interação para se procurar e colocar a camisinha, o que percebo ser elaborado na decisão do uso ou não do preservativo é a construção do que Pelúcio, em sua pesquisa sobre a prevenção de doenças na prostituição travesti, chama de uma "hierarquia de riscos" (2009). Um exemplo clássico é aquele referente às posições durante o ato sexual, da exigência da camisinha se você for atuar como passivo naquela interação, mas a não obrigatoriedade se você for o ativo, "só coloco se pedem, senão vai sem mesmo". Este pensamento seria justificado pela ideia de que é só quando você está sendo passivo que há mais chance de se contaminar com alguma coisa. Ou de como após uma interação sem o preservativo que eu acompanhei, aquele que estava sendo o passivo se virou e disse para o outro: "nossa, que loucura! A gente nem chegou a usar nada!", e o outro respondeu: "Pode ficar tranquilo, eu sou casado". Como se o fato de estar casado fizesse dele uma pessoa com menos perigo de contaminação, mais pura.

Esta hierarquia relaciona-se com a classificação do(a) parceiro(a) como alguém conhecido(a)/familiar e desconhecido(a)/estranho, e as associações que daí advêm: confiança, segurança versus perigo e risco, respectivamente. No cômputo da elaboração dessa escala hierárquica entram, ainda, as práticas eróticas e que posição se assume nelas. O ativo/penetrador/emissor, tanto na penetração anal ou oral, vê seus riscos diminuídos. Enquanto o(a) parceiro(a) passivo(a)/ penetrado(a)/receptor se arrisca consideravelmente. E aí entra todo o simbolismo, não só dos significados da cadeia passivo/penetrado/receptor, associado ao desvio, ao perigo e ao impuro, como também as representações acerca dos fluidos corporais (Pelúcio 2009:174-175).

A ideia das práticas e dos "prazeres perigosos" (Gregori 2010) precisa ser observada com mais atenção. O "se jogar", se arriscar, ou se colocar numa situação de potencial perigo, principalmente naqueles relativos a algum 
tipo de contaminação, não acontece em função de algum desconhecimento ou falta de informações técnicas sobre formas de contágio, nem mesmo é uma "atitude rebelde" de desobediência ao controle médico dos "poros e das paixões" (Perlongher 1985). O que eu percebo é a elaboração de um conhecimento outro, próprio, que usa vários elementos, sejam eles vindos do saber médico, do cotidiano, e/ou de experimentações próprias. O que há ali é uma "ciência do concreto", a elaboração de um saber construído e posto em prática sobre o que é risco, o que é perigoso, sobre formas de contaminação e maneiras e técnicas para evitá-las. ${ }^{24}$

Expor-se ou não a algo é como um cálculo infinitesimal feito a partir do prazer que se sente, da intensidade da interação e do que se percebe como riscos menores ou maiores. Tomemos um exemplo para que fique mais claro, o do sexo oral: durante todo o trabalho de campo nunca observei alguém fazer sexo oral usando preservativo; ainda que esta seja uma recomendação médica, sabe-se pela divulgação de pesquisas e de protocolos médicos (que não são completamente desconhecidos dos interlocutores) que a possibilidade de contaminação por esse ato é muito pequena - pouco risco diante da quantidade de prazer que traz. Isto não quer dizer que não haja várias técnicas.

Ainda no exemplo do sexo oral sem preservativo, vários conhecimentos são compartilhados: você precisa observar se o pau é muito "babão" (ou seja, se ele libera muito líquido seminal); se você pode guardar o líquido na boca e cuspir de tempos em tempos, evitando engolir a "baba". É melhor evitar a ejaculação direto na boca; se não conseguir evitar, uma opção é que o esperma seja imediatamente cuspido; se não quiser ou não conseguir cuspir, então que ele seja engolido rapidamente ("o ácido do estômago mata todos os vírus, é mais fácil se contaminar na boca do que no estômago"); lavar a boca com enxaguante bucal depois é outro cuidado para se diminuírem os riscos de alguma contaminação. Contrário a este "ensinamento", certa vez ouvi no banheiro: "se você fez sexo oral, eu não indicaria fazer isso (usar o enxaguante bucal). Listerine tem ácido e pode machucar". Trata-se de um conjunto de conhecimentos, receitas pessoais e uma determinada medicina particular criada e compartilhada pelas pessoas ali. Há uma ideia do que se pode ou não fazer, do que pega ou não pega, do que é risco ou não, enfim, uma profilaxia própria. Não é só a hierarquização de riscos, é uma elaboração particular de conhecimento, tal como uma "ciência do concreto". ${ }^{25}$

Outro exemplo é o da própria penetração anal: deve-se primeiro reparar no pênis e evitar os "paus babões". Se a interação estiver caminhando para o não uso do preservativo, começa-se colocando o pênis aos poucos: "vou só brincar, só colocar a cabecinha, só mais um pouco". O uso de bastante gel ou 
saliva para evitar o atrito é recomendado. Se a penetração sem a camisinha ocorrer de fato, que se evitem os movimentos bruscos ou uma penetração mais agressiva, "assim você não rompe vaso nenhum, não se machuca, mas é preciso estar bem relaxado e nunca, nunca, deixe gozar dentro, porque esse é que é o perigo todo, sempre fora" ${ }^{26}$

Percebe-se toda uma gradação de riscos em que uma série de cálculos deve ser feita para dosar o que é mais ou menos perigoso aliado ao quanto de prazer pode ou não proporcionar. Assim, são decididos e negociados o uso de preservativos, o contato com o esperma, as práticas sexuais em geral. "Qual o perigo de pegar alguma coisa com isso? Qual o prazer que me proporciona? O quanto estou disposto a arriscar?" - estas são perguntas feitas a todo momento, a cada nova interação e a cada nível de intensidade das práticas. Além disso, outros fatores são agenciados nesses cálculos, como a apresentação corporal do outro, cheiros, toques, cor, idade etc. Você pode estar mais disposto a determinadas práticas com uma pessoa do que com outra ao levar esses fatores em consideração, aquelas pessoas que, por inúmeras razões, podem "te passar mais confiança" (Gambôa 2013).

Os caras escolhem com quem vão transar sem camisinha. Olham um cara gato, corpão, com aparência saudável, tranquilo, imaginam que uma pessoa daquela não deve ter nada. O cuidado vai aparecer com aqueles que eles acham que estão mal cuidados, magros demais, com aparência de doentes ou que sejam muito putos que devem transar com um número muito grande de pessoas e não se cuidam e tal...

Claro que a erotização dos riscos não é necessariamente o mesmo de algum desejo ou procura pela morte, mas sim de eventos ou situações que envolvem um risco "tornando a própria vida parte integrante do jogo que se quer jogar" (Rocha 2011:63). Assemelha-se ao que os praticantes de esportes radicais pesquisados por Verônica Rocha colocam como uma tensão que traz um sentido à vida que se quer viver: colocar a vida em risco e "brincar" com ela não é de forma alguma procurar a morte, mas sim intensificá-la, o risco e o perigo libertando de uma "morte em vida", o desejo de estímulos sensoriais que proporcionem um modo de vida "original", "grandioso", "prazeroso", "ativo" e "excitante" (Rocha 2011:78).

Não que a opção mais extrema pelo perigo também não possa ser tomada. A prática sexual bareback e seus riscos implícitos é muito desejada nesses espaços. ${ }^{27}$ Durante o trabalho de campo foi possível perceber a organização de várias outras festas paralelas que se colocam como exclusivamente de prática bareback, e também de eventos de "roleta russa", ou mesmo de "festas de conversão" (trata-se da soroconversão, de soronegativo para soro- 
positivo), em que se sabe da presença de soropositivos e há o risco de uma situação de possível contaminação. São festas diferentes (e mais específicas) daquelas que pesquisei, mas que, de certa forma, também as atravessam, com participantes que frequentam ambas. Mas mesmo nas festas de orgia é possível ver práticas em que se deixa "gozar dentro", "engolir o gozo", "tomar o leite", "espalhar ele pelo corpo", e há relatos de participantes que recolhiam camisinhas usadas do chão dessas festas para tomarem o gozo ou se banharem.

Lembro da minha surpresa ao ver um interlocutor conhecido saindo do meio de uma aglomeração no dark e aproximar-se de mim, pegar minha mão para passar na perna dele dizendo sorrindo: "é porra seca. Tô todo colado. Acho que uns dois gozaram dentro", levou a minha mão a seu ânus e disse: "sente, coloca a mão aqui para você ver como ela está escorrendo". Por ser uma pessoa com quem estabeleci um contato maior, não pude evitar a reprodução de um discurso normalizador e de cuidado com a saúde, ao que fui rebatido com um "tenho o meu direito a me foder se eu quiser", para o qual não tive resposta. Meu choque vinha de uma dificuldade inicial de entender (ou aceitar) que também se pode optar pelo risco, por um caminho perigoso (ou por uma outra noção de "cuidado") em prol de outra coisa, daquilo que se acredita que seja o melhor. Esse direito se relaciona com o que eles chamam de "ligar o foda-se", jogando-se perdidamente no prazer intenso, no excesso, em uma "linha de abolição", tal como Deleuze e Guattari nomeiam movimentos de autodestruição (1995, vol. 3:112).

$\mathrm{Na}$ tensão entre prazer e risco, os elementos do consentimento e da responsabilidade voltam com força, seja para consigo mesmo, seja também com o outro. O que meus interlocutores apontam é que mesmo os riscos precisam ser consentidos.

Cara, eu vi gente ali que nem via quem metia nelas, ainda mais se estavam com camisinha ou se aquela camisinha estava sendo usada em outro. Saía um, outro ocupava o lugar e o cara nem aí.

Eu acho que o outro tem que ter caráter, uma coisa é o cara avisar pra você: 'Olha, eu sou soropositivo. Você quer fazer com ou sem camisinha?'. Ou mesmo que ele não tenha nada, tem que acordar antes! Se o cara tenta sem perguntar, eu fico desconfiado e não transo mais com a pessoa.

Se você tá chupando o cara, ele tem que te avisar que vai gozar antes, isso pra mim é muito básico. Pra você se preparar, pra poder decidir se deixa ou não. E se eu não quero? E se eu não gosto de porra? E mesmo que eu goste, quem disse que eu vou querer engolir a tua? Eu fico muito puto quando o cara acha que pode gozar. A mesma coisa de querer gozar no rosto ou no cu e, principalmente 
essa coisa de camisinha, é "de bom tom" pedir antes, não tô falando nem de educação não, por uma coisa meio de ética também, sabe? Como é, já vai sair gozando ou metendo assim?

No limite, portanto, a decisão de fazer "com capa" ou "no pelo" e do contato mais direto com o esperma do outro deve ser acordada consensualmente. Porém, durante o trabalho de campo repercutiu uma notícia nos meios midiáticos relacionada ao que ficou conhecido como "Clube do Carimbo". A polêmica que se iniciou a partir de um blog da internet, já bastante comentada nas festas, e ganhou repercussão após algumas matérias de tom sensacionalista no programa dominical "Fantástico", da Rede Globo. O blog trata do compartilhamento de textos, fotos e vídeos sobre a prática bareback, incentivando que pessoas soropositivas transmitam o vírus (que "carimbem") de propósito as outras, a partir de técnicas, como furos na camisinha antes do ato ou retirando o preservativo durante o sexo sem que o parceiro perceba. ${ }^{28} \mathrm{~A}$ intencionalidade da contaminação retirando o poder de consentimento do outro fez com que durante alguns meses este fosse o tópico de debate em algumas conversas na festa. Muitos pesquisadores da área relativa à saúde se pronunciaram para desmistificar alguns sensos comuns sobre a ideia de contaminação colocados ali e do risco de que essa midiatização sensacionalista gerasse um "pânico moral" (Rubin 1998) e uma perseguição das pessoas que convivem com o HIV e com aqueles que, costumeiramente, são associados à doença: homossexuais, transgêneros e profissionais do sexo.

Nas festas, a ideia de uma contaminação intencional pairou como um fantasma por alguns meses, às vezes sendo ironizada e tratada na chave do riso como maneira de exorcizá-la, mas nem por isso sem ser levada a sério: "eu, por via das dúvidas, prefiro usar a minha camisinha e sempre confiro com a mão pra sentir se o cara tá usando mesmo. Já fazia isso antes dessa história, mas agora redobro minha atenção, porque há mesmo alguns caras que tiram no meio, isso eu já vi acontecer, é muito escroto". ${ }^{29}$

Não quero afirmar que toda prática bareback tenha a intencionalidade de uma contaminação, ou que o sexo sem camisinha seja uma questão de abuso e muito menos que os espaços das festas sejam "antros de doenças e contaminação", tal como pude ouvir em algumas apresentações sobre essa pesquisa em seminários e congressos (Barreto 2018b). Esta seria uma associação injusta e inconsequente. ${ }^{30} \mathrm{Um}$ dos participantes da festa, por exemplo, possui um blog bastante visitado e comentado pelos outros frequentadores, no qual compartilha postagens de fotos e vídeos pessoais sobre a prática que é chamada de sexo pig (fetiches que envolveriam humi- 
lhação, excrementos, vômitos, fisting, o não uso de preservativo, peidos, dentre outros). Trago um trecho de uma de suas postagens no blog, em que em um imenso "texto desabafo" ele se defende de críticas ao conteúdo de suas postagens.

O propósito do meu projeto na net é o de única e exclusivamente levar entretenimento adulto diferenciado aos meus leitores, falar do sujo, do insano, do "imoral", o que a sociedade descarta, por julgar inapropriado, como a bosta, o mijo, o catarro, a submissão (consensual). Nada que você vê no meu site é forçado. Tudo é feito de forma consensual, inclusive, hoje, nem busco mais parceiros para fodas, eles é que me procuram no falecom do meu site. Tenho recebido centenas de pedidos de putas querendo ser usadas, esculachadas, dispostas até a arriscarem seus "casamentos", suas carreiras profissionais, em nome de um momento de libertação. Sim, um momento em que não existe o pudor social, o peso na consciência por comer um sebo, por lamber um cu cagado, ou por gostar de um tapa na fuça sendo lembrado de sua condição "subconsciente" de capacho. [...] Sou tachado de homofóbico, de precursor da disseminação do HIV no Brasil, de doente mental, de alguém que não aceita a sua condição sexual de sentir desejo por homens. Porém, o que poucos não sabem é que sou muito convicto dos meus valores, sei bem o que sou, o que represento, o que me limita, o que quero e o que não quero em cima e fora de uma cama. [...] Minha luta é pela liberdade de imprensa, é pelo fim da hipocrisia, pelo direito de se tirar a roupa e decidir: Com capa, ou sem capa?? Afinal, é a sua vida. E só a você ela importa. Ninguém é enganado, ninguém desconhece os riscos e prazeres que um sexo sem proteção pode causar, e suas consequências, muitas vezes irreversíveis. Mas volto a dizer: É a sua vida. Cada um tem a sua, para que se respeitem decisões, espaços, limites, vontades. Meu papel é mostrar às pessoas que se pode sentir prazer pelo sujo, sem ser prognosticado como "anormal". Sim, você pode beber urina e ter amigos, falar de futebol. Sim, você pode dar a bunda, tomar um tapa, ser chamado de "puta" e descer da cama e ter o respeito como o "homem" que tu és fora dela. Enfim, fica o meu reforço de que não sou "Discursador de Ódio" contra homossexuais, não prego a AIDS no mundo, nem tão pouco quero o seu amor e a sua aprovação. O meu grito de SIMMMMMMMMMM à liberdade de expressão, sim à prática do que se tem vontade, sim ao direito de decidir o que é melhor para as nossas vidas, saúde, papel, moral e, sobretudo, o que é melhor para o nosso prazer!!!! "Cada um sabe a dor e a delícia de ser o que é" (Fonte: http://abagacadoguttao.com.br/blog-2/). 


\section{Conclusões}

A putaria, ou a própria festa, tal como me apresentam seus participantes, é um acontecimento de "jogação", de "safadeza", de "brincadeira" que precisa guardar uma relação de equilíbrio com as outras áreas da vida dessas pessoas. Os homens que frequentam essas festas não trabalham segundo uma lógica disjuntiva (ou... ou...). A maneira como eles parecem lidar com os diferentes "mundos" e "categorias" em que vivem assemelha-se muito mais a uma lógica da conjunção (e... e...), o que não quer dizer que elas se misturem ou que não apresentem riscos à sua manutenção simultânea. A maioria das pessoas com as quais conversei, por exemplo, afirma preferir que a ida a esses lugares não seja do conhecimento de amigos e familiares, sem contar o fato do número representativo de pessoas casadas ou em alguma forma de relacionamento que também aparecem nas festas. Precisa-se saber gerenciar a "putaria" com o restante da vida. Aproxima-se daquilo que Eugênio (2006) chama de "hedonismo competente", uma competência em saber articular os compromissos da vida cotidiana com as práticas de "perdição", de "êxtase". Um modo de existência, portanto, que busca uma conjunção entre a busca pela intensidade descrita nas práticas neste texto e o cotidiano da vida ordinária, a partir de uma "estética da existência" (Foucault 2006) que lida justamente com um manejamento dos limites entre o prazer e o risco nessas festas.

Neste artigo busquei dar conta do desejo de uma experimentação intensa que percebi ser principal condição de possibilidade e de entendimento de certas práticas sexuais performadas de maneira coletiva. Intensidade esta que proporciona uma experiência tanto prazerosa quanto arriscada dos sujeitos com os seus próprios limites e com os do(s) outro(s). Deleuze e Guattari afirmam que a potencialidade da afetação nos encontros dos corpos pode ser pensada através da questão "o que pode o corpo?" (1995, vol. 4:39-47). Acredito que esta questão nos ajude a pensar as práticas e os desejos descritos ao longo deste artigo. A pergunta "o que pode o corpo?" não é minha no sentido de que não sou eu quem a está trazendo de fora. Ela é colocada em prática a todo momento por esses homens a cada ida nesses eventos, cada interação sendo uma oportunidade para se testar: "quais os meus limites? o que eu posso fazer? o que o outro pode fazer? até quanto eu ou ele aguenta?". Seja numa questão quantitativa (de "quantos eu comi", para "quantos caras eu dei", ou "quantas vezes eu gozei"), seja também qualitativa, de intensidade das interações, "até que ponto eu aguento nesse encontro?", "mais forte ou mais calmo, mais rápido ou mais devagar?", "está me machucando, mas permaneço aqui ou não?" , "qual o meu limite?"; "o 
que pode o meu (seu) corpo?", ela é feita até mesmo na perda da conta das interações realizadas durante a festa. ${ }^{31}$

No meu campo percebo como isto está presente de certa forma (aliado à ideia de experimentação e de intensidade das interações e da efervescência) ao se pensar em práticas "novas". Coisas que esses homens não fariam em outros contextos encontram nas festas um espaço propício em que são ofertadas diversas práticas novas e diferentes, possibilitando a sua experimentação (mesmo que ela se restrinja a esses eventos) e, a partir daí, podendo entrar em seu repertório de gostos, ou então serem "curtidas" apenas nesses eventos: "dar o cu", "beber porra", sexo coletivo, a "putaria"...

Como bem aponta Lima (2015:113-114), acreditando que existe um limite predeterminado para nosso corpo: "acredita-se que já sabemos o que pode um corpo. Existe sempre um especialista para determinar o que pode um corpo". Só que o que algumas experiências intensas (como drogas, música, bebidas, esportes radicais, sexo etc.) colocam são experimentações que empurram, contornam, atravessam, enfim, retraçam as linhas de nossos limites. "Todas as faculdades podem ser levadas a seu limite, através da potência de algum estado" (Perlongher 2012).

Um cuidado, apontado anteriormente, é o dos riscos e dos perigos implícitos nessas experimentações, já que "o que rompe se rompe forte demais e pode destruir tudo" (Perlongher 2012), daí a recorrência das "fissuras" enquanto acontecimentos de "tensão-rompimento" ou de se atingir e mesmo atravessar determinado limite. A questão é que não se sabe de antemão até que ponto se pode ir, "como se vai até o limite visto que ele não preexiste e precisa ser inventado, traçado?" (Lima 2015:114). O que os participantes das festas colocam em prática pelo princípio da "putaria" é essa experimentação intensa de seus próprios limites.

Recebido em: 21/03/2018

Aprovado em: 15/03/2019

Victor Hugo de Souza Barreto

Doutor em Antropologia pela Universidade Federal Fluminense. Pós-doutor pelo Programa de Pós-Graduação em Antropologia Social do Museu Nacional/ UFRJ. Autor dos livros: Vamos fazer uma sacanagem gostosa? Uma etnografia da prostituição masculina carioca e Festas de orgia para homens: territórios de intensidade e socialidade masculina.

E-mail para contato: torugobarreto@yahoo.com.br. 


\section{Notas}

1 A tese defendida deu origem à publicação: Barreto (2017b).

2 Sobre mais detalhes do recorte de participação relativo à masculinidade nesses espaços e de como a questão de gênero é produzida nesses eventos, conferir Barreto (2018a).

3 A minha presença nesses eventos foi autorizada por todos os seus respectivos organizadores, que não só aceitaram me conceder entrevistas como também permitiram a identificação comercial das festas. Minha preocupação com o anonimato recaiu sobre os participantes porventura identificados no texto com nomes fictícios ou apenas por descrições corporais. As falas dos interlocutores foram recuperadas a partir das minhas notas em um caderno de campo que era preenchido após os eventos. Para maiores detalhes sobre a minha inserção no campo e os desafios metodológicos na pesquisa sobre práticas sexuais efetivas, ver Barreto (2017b, 2018b).

4 Em Barreto (2017b) desenvolvo essa ideia a partir do caráter de "clube" ou mesmo de "sociedade exclusiva", "casa dos homens" ou "casa dos machos" que esses espaços carregam, produzindo um determinado "proceder" entre esses homens participantes. As práticas descritas ao longo deste artigo também não são tomadas como algo da totalidade da vida dessas pessoas. Não que pensar a "totalidade" seja a minha intenção aqui (ou que a Antropologia ainda reivindique para si esse papel), mas de, justamente, pensar o local desses eventos, o desejo pela intensidade dessas festas, aquilo que é produzido nas orgias e na prática do sexo coletivo que faz com que seus participantes as desejem e retornem a elas. Para usar uma imagem elaborada por Deleuze e Guattari: as práticas desse campo seriam como rizomas que brotam nos cotovelos dos galhos da "vida real".

5 É entendido pelo autor como a atualização de um valor englobante a partir de estratégias e práticas que preservem ou salvaguardem a vida o máximo possível em sua extensão, daí ser relacionado em diversos contextos a um certo ascetismo que se contraporia a um hedonismo (Duarte 1999).

6 O que apresento nessa introdução sobre a busca da intensidade é uma versão resumida da discussão que faço em Barreto (2018c).

7 Faço essa comparação de diferentes cenários etnográficos guardando as devidas proporções, já que cada um desses contextos possui as suas especificidades. Entendo também que trato neste texto de práticas sexuais que sofrem diversas ordens de opressão social com base na estigmatização da homossexualidade, característica nem sempre presente ou definidora dos outros contextos citados. A aproximação está nas mais diversas experimentações corporais, sensoriais e emocionais enquanto produtoras de subjetividade.

8 Em Barreto (2017b) explico que analisei as festas de orgia masculinas a partir daquilo que eu chamei de "princípios", ou seja, dos pontos nodais com os quais meus interlocutores organizavam esses eventos, tanto em sua ética local quanto em 
roteiros sexuais correspondentes. São três: o "princípio da masculinidade" (no qual se demonstra toda a importância de valorização de uma determinada masculinidade baseada, em sua maioria, em valores normativos); o "princípio da discrição" (em que se explicitam práticas e formas de se relacionar que valorizam o segredo, o anonimato, a escuridão e a desidentificação); e o "princípio da putaria" (aquele que se relaciona com a busca da intensidade e da efervescência produzida nesses eventos, de um modo singular de engajamento no mundo). Estes princípios são os responsáveis por uma determinada produção subjetiva valorizada nesses espaços: a do "macho, discreto e puto".

9 Poppers é o nome que se dá a uma substância inalante composta por nitritos voláteis, semelhante ao lança-perfume e ao "loló", comercializado em pequenos vidros. Considerada uma substância psicoativa, possui efeitos prazerosos rápidos e breves. Ainda que não seja comercializado no Brasil, o acesso pela internet e por encomendas em sex shops é facilitado.

10 Com excessão da "Orgia em Alto Mar", quando um barco é alugado para um passeio pela Baía de Guanabara e algumas de suas ilhas mais desertas. O evento se diferencia pela comida e bebida que é servida livre durante o passeio e que é consumida em excesso. Porém, esse evento tem um clima muito mais de confraternização entre os habituais frequentadores da festa (o que não impede nem desestimula as interações eróticas).

11 Viagra e Pramil são os nomes comerciais de fármacos cujo princípio ativo é a sildenafila, indicada no tratamento para disfunção erétil. Como não há necessidade de uma autorização médica para o consumo no país, a sua venda é facilitada em qualquer drogaria e costuma ser utilizada como garantia de ereção, daí ser também um recurso importante para atores pornôs e garotos de programa (Barreto 2017a).

12 O poppers, por exemplo, contribui para o relaxamento muscular facilitando a penetração.

13 Ainda que os organizadores afirmem não haver funcionários suficientes para vigiarem e controlarem tudo aquilo que é feito durante as festas, alguns deles me confidenciaram que clientes mais antigos ou amigos que costumam frequentar a festa acabam funcionando como "olheiros" ou "seguranças" daquilo que acontece nas interações. Se esses informantes presenciam algum uso de drogas, furtos, brigas ou comportamento inadequado para o espaço, rapidamente repassam a informação para os organizadores, que tomam as devidas providências, como a expulsão de clientes ou a sua proibição em festas futuras. Nesse sentido, os próprios organizadores adiantam alguns limites à participação no evento e algumas regras básicas a serem respeitadas por todos.

14 MDMA, uma forma do ecstazy, também chamada de "Michael Douglas".

15 Aproveitando-se das novas plataformas de comunicação, como os aplicativos para encontros sexuais, começam a aparecer eventos organizados para a prática do chem sex (algo como sexo químico). São pessoas que se reúnem para "sessões" de sexo de longa duração sob o efeito dessas mesmas substâncias químicas, algo como 
"raves sexuais". A prática, que se iniciou nas cidades de Londres e Madrid, mas que, pelo que pude observar, começou a chegar a São Paulo, é combinada, em sua maioria, via aplicativos de celular por participantes que se identificam a partir da \#chemsex em seus perfis ou mesmo da busca por parceiros para "sexo aditivado". Esses eventos se diferenciariam das festas de orgia pesquisadas não só por não apresentarem uma organização de espaços comerciais voltados para esses eventos, mas também por serem feitas em âmbitos mais privados, onde há a obrigatoriedade do uso das substâncias. Aponto como essa questão das drogas se diferencia na cena recente das festas independentes de São Paulo, principalmente aquelas cujos temas são o sexo e a nudez, vindas da cena eletrônica e muito mais permissivas em relação ao uso e à experimentação de drogas (Braga 2018).

16 Twink ou twinkie é uma categoria de classificação da indústria pornográfica para caracterizar homens com um tipo físico juvenil: magros, baixos, sem pelos etc.

17 O debate sobre as relações entre violência e erotismo não é novo. Vem desde as reflexões de Bataille a partir de um ponto de vista filosófico e ganha força nas ciências sociais dos anos 1980 em diante com os trabalhos de autoras feministas, como Vance (1984), Califia (1994) e Rubin (2001). No Brasil, pesquisadoras como Gregori (2003, 2004, 2010), Facchini (2008) e Díaz-Benítez (2012 e 2015) também trazem em diversos trabalhos importantes contribuições à discussão e à história dessa tensão.

18 A própria ideia de que práticas de violência podem ser erotizadas e que a encenação consensual simule algo não consentido, como na cena de "curra" com o twink narrada mais acima, são indicativos disso.

19 BDSM (Bondage, Disciplina, Dominação, Submissão, Sadismo e Masoquismo) é a sigla que agrupa um conjunto de práticas eróticas que ritualizam jogos de poder.

20 Talvez o leitor tenha estranhado a ausência de certos marcadores nas descrições trazidas neste texto, tais como raça, idade, classe e gênero. Preferi assumir esta escolha arriscada, na medida em que não teria espaço aqui para os aprofundamentos necessários sobre os efeitos produzidos por esses marcadores em diferentes momentos por mim observados. Uma análise mais detalhada dos efeitos nesse campo é apresentada em Barreto (2017b, 2017c, 2018c, 2019).

21 Agradeço à professora Laura Lowenkron por me chamar a atenção para este ponto.

22 A profilaxia pré-exposição ao HIV (PrEP) é uma estratégia de prevenção que envolve a utilização diária de um medicamento antirretroviral (ARV), cuja marca mais famosa é o Truvada, por pessoas não infectadas, para reduzir o risco de aquisição do HIV através de relações sexuais. No Brasil, a utilização do remédio foi recentemente autorizada (dezembro de 2017). Durante o trabalho de campo ainda se encontrava na fase de testes e vi por um tempo um cartaz da Fiocruz na recepção de uma das festas convidando interessados a participarem de testes e pesquisas referentes à aplicação do remédio. Venho no Pós-doutorado acompanhando os impactos desses novos protocolos nos roteiros sexuais de meus interlocutores. 
23 Um dos exemplos de como essas novas profilaxias vêm deslocando certas percepções sobre "saúde", "doença", "risco" e "cuidado" é justamente a facilidade com que esse interlocutor revela a sua sorologia para HIV, não mais entendida como um segredo vergonhoso ou estigmatizante, nem mesmo como uma "sentença de morte", ainda que o silêncio desconfortável depois da fala aponte o quanto esse entendimento está em processo de transição. Para um panorama sobre a história da epidemia de HIV/Aids no Brasil e de como grupos mais vulneráveis, Estado e sociedade civil trataram a questão até o atual momento em que caminhamos para o início da quarta década da epidemia no mundo, ver: Terto Jr. (2002); Parker e Terto Jr., (2002); Bastos (2006).

24 Em O Pensamento Selvagem (1989), Lévi-Strauss argumenta contra a ideia de que os povos indígenas tenham algum tipo de lógica ou pensamento menos racional que a dos europeus e chamou o pensamento elaborado pelos nativos de "ciência do concreto". O autor argumenta que havia ordem e método no que a princípio poderia ser classificado como associações caóticas entre elementos da natureza como plantas e animais e sua relação com instituições sociais. "Eram o resultado não da falta de razão, mas, em certo sentido, de seu excesso". Agradeço também ao primeiro parecerista anônimo deste artigo por me lembrar que essa "racionalidade científica" nativa analisada por Lévi-Strauss partia de uma "lógica do sensível": "Enquanto a ciência moderna parte da abstração para o concreto, os indígenas partiriam do concreto, ou das experiências sensíveis, para a abstração". Ainda que essa lógica seja perceptível também entre nós.

25 O fato de meus interlocutores não desconhecerem dados e elementos da "ciência" não quer dizer que ela não possa ser mais um dos elementos ou dos recursos usados na bricolagem intelectual da "ciência do concreto". Não tomo tal teoria nativa como uma interpretação possível do conhecimento científico, porque isso retiraria não só seu potencial de significação, como também colocaria a ciência ocidental como verdade última no campo em questão, o que não é o caso.

26 Em Barreto (2018d) analiso como tais práticas e roteiros sexuais colocam desafios perante as políticas de saúde pública contemporâneas, principalmente a partir das novas profilaxias referentes ao HIV/Aids. Já em Barreto (2018e) aprofundo com mais detalhes a relação sempre tensionada nesses espaços entre risco, prazer e técnicas de cuidado de si.

27 Sobre a prática barebacking, conferir artigo de Garcia (2009) que problematiza a origem do termo e busca trazer algum entendimento sobre esse desejo em um contexto maior de políticas de saúde e do que o autor chama de "terrorismo biológico". Importante destacar que o trabalho de campo realizado foi anterior à distribuição facilitada da PEP (profilaxia pós-exposição) e da PrEP (profilaxia pré-exposição). De acordo com o site oficial do governo brasileiro (http://www.aids.gov. br), a PrEP (que começou a ser implementada no Sistema Único de Saúde só no final de 2017) é usada como estratégia de intervenção para a prevenção da transmissão entre "populações prioritárias" - casais sorodiferentes, HSH, gays, profissionais do sexo, travestis, transexuais, usuários de drogas e pessoas privadas de liberdade e em situação de rua. A PrEP consiste no uso diário de antirretrovirais por pessoas não 
infectadas, mas em risco elevado de infecção pelo HIV. E a PEP é uma medida de prevenção que consiste no início do uso de medicamentos até 72 horas decorridas de uma provável exposição ao vírus HIV. Ela é utilizada, basicamente, em duas situações: em casos de risco de contaminação por HIV de profissionais de saúde na atividade laboral, devido a acidentes, e em casos de relações sexuais em que ocorre falha nas medidas de prevenção, para reduzir o risco de transmissão do HIV.

28 No blog percebe-se o uso de termos, gírias e símbolos próprios para a prática. O reconhecimento de alguns, por exemplo, por uma tatuagem com o símbolo de "risco biológico".

29 Esta questão mereceria um espaço de desenvolvimento maior que me falta aqui. Mas é importante destacar o posicionamento mais recente de um dos organizadores dos eventos sobre esta questão: "Quem curte foder sem preservativo sabe dos riscos e das consequências e as assume sem problemas e neuroses! Em tempos de PEP e PrEP só pega algo quem quer! Ninguém aqui é inocente. Praticar sexo sem camisinha não é considerado crime. O que é crime, segundo os artigos 129, 130 e 131 do Código Penal Brasileiro, é uma pessoa transmitir propositalmente qualquer doença sexualmente. O que num grupo bareback não se encaixa! Não temos a obrigação de avisar nada! Se o sexo é consensual sem preservativo, cada um sabe das suas responsabilidades. Outra coisa, você até pode ter o fetiche de carimbar ou ser carimbado, mas como isso é possível hoje em dia? Quem é soropositivo toma o coquetel, fica com carga viral indetectável e não transmite a doença; quem não é soropositivo toma PEP ou PrEP e não pega!".

30 Até porque a prática do sexo sem camisinha pode adquirir sentidos diferentes a depender do contexto. A decisão de não se usar preservativo nas relações amorosas (tanto hetero quanto homossexuais) pode significar, por exemplo, um voto de confiança e um passo maior na intimidade entre o casal. Ou mesmo na prática da prostituição, em que o uso do preservativo é associado à dinâmica do programa e está ausente nas relações de contexto amoroso. Interessante perceber como o termo bareback se prendeu ao contexto das relações sexuais entre homens e sempre atravessado pelo debate da contaminação.

31 Apresento com mais detalhes a relação entre a busca de uma "repetição" nessas orgias e a questão do que pode o corpo em Barreto (2018c). 


\section{Referências bibliográficas}

BARRETO, Victor Hugo de Souza. 2017a. Vamos fazer uma sacanagem gostosa? Uma etnografia da prostituição masculina carioca. Niterói: EDUFF. 2017b. Festas de orgia para homens: territórios de intensidade e socialidade masculina. Salvador: Editora Devires.

. 2017c. "'Putaria' enquanto conceito: desejo e sexualidade na prática orgiástica". Bagoas, v. 11, n. 17.

. 2018a. "'Venha se você for homem': O princípio da masculinidade em orgias entre homens". Sexualidad, Salud y Sociedad. Revista Latinoamericana, n. 29:99-122.

. 2018b. "Quando a pesquisa é o problema: o tabu no estudo das práticas sexuais". Cadernos de Campo, USP, v. 1, n. 26:271-294.

. 2018c. "O 'princípio da putaria' nas orgias masculinas: diferença e singularidade no corpo orgiástico". In: Camila Fernandes; Everton Rangel \& Fátima Lima (orgs.), (Des)Prazer da norma. Rio de Janeiro: Papéis Selvagens.

. 2018d. "Prazer e risco: o desafio entre as políticas de saúde contemporâneas relacionadas ao hiv/aids e os roteiros eróticos de homens que fazem sexo com homens". In: Rosana Castro; Cíntia Engel \& Raysa Martins (orgs.), Antropologias, saúde e contextos de crise. Brasília: Sobrescrita. pp. 149-162.

. 2018e. "Risco, prazer e cuidado: técnicas de si nos limites da sexualidade". AVÁ - Revista de Antropologia, Buenos Aires, v. 31:119-142.

. 2019 (no prelo). "Sexo Pig: algumas notas sobre prazeres extremos". In: Thiago Oliveira \& Hélder Maia (orgs.), Práticas Sexuais: itinerários, possibilidades e limites de pesquisa. Salvador: Editora Devires.

BASTOS, Francisco Inácio. 2006. AIDS na Terceira Década. Rio de Janeiro: Ed. da Fiocruz.

BRAGA, Gibran Teixeira. 2018. "O fervo e a luta": políticas do corpo e do prazer em festas de São Paulo e Berlim. Tese de Doutorado em Antropologia Social, Faculdade de Filosofia, Letras e Ciências Humanas, Universidade de São Paulo.

CALIFIA, Pat. 1994. Public sex: the culture of radical sex. São Francisco: Cleis Press.

DELEUZE, Gilles \& GUATTARI, Félix. 1995. Mil Platôs. Capitalismo e esquizofrenia. 5 vols. Rio de Janeiro, Editora 34.

DELEUZE, Gilles \& PARNET, Claire. 1998. Diálogos. São Paulo: Escuta.

DÍAZ-BENÍTEZ, María Elvira. 2012. "Sexo com animais como prática extrema no pornô bizarro". Cadernos Pagu, Unicamp, v. 38.

. 2014. "O sexo sempre é culpável? Notas sobre prazeres, perigos e fissuras na sexualidade". Matéria publicada no blog Folha do Gragoatá, Rio de Janeiro. Disponível em: http://afolhadogragoata.blogspot. com.br/2014/06/o-sexo-sempre-e-culpavel-notas-sobre.html? m=1. Acesso em 12/04/2019.

. 2015. "O espetáculo da humilhação, fissuras e limites da sexualidade". Mana, v. 21:65-90.

DUARTE, Luiz F.D. 1999. "O império dos sentidos: sensibilidade, sensualidade e sexualidade na cultura ocidental moderna". In: Maria Luiza Heilborn (org.), Sexualidade: o olhar das ciências sociais. Rio de Janeiro: Jorge Zahar. pp. 21-30. 
EUGÊNIO, Fernanda. 2006. Hedonismo Competente: Antropologia de urbanos afetos. Tese de Doutorado, Museu Nacional/UFRJ.

FACCHINI, Regina \& ROSSETTI, Sarah. 2013. "Praticamos SM, repudiamos agressão: classificaçoes, redes e organização comunitária em torno do BDSM no contexto brasileiro". Sexualidade, salud y sociedad: Revista latinoamericana, n. 14:195-228, ago.

FACCHINI, Regina. 2008. Entre Umas e Outras: mulheres, (homo)sexualidades e diferenças na cidade de São Paulo. Tese de Doutorado em Ciências Sociais, Instituto de Filosofia e Ciências Humanas, Unicamp, Campinas.

FERREIRA, Pedro Peixoto. 2006. Música eletrônica e xamanismo: técnicas contemporâneas do êxtase. Tese de Doutorado, IFCH-Unicamp.

FOUCAULT, Michel. 2006. "O uso dos prazeres e as técnicas de si". In: Ditos e escritos: ética, sexualidade e política. Vol. 5. Rio de Janeiro: Forense Universitária.

GAMBÔA, Ricardo Fernandes. 2013. De prazeres e perigos: abordagem etnográfica dos roteiros eróticos de homens que fazem sexo com homens e desafios à prevenção do HIV na região central da cidade de São Paulo. Dissertação de Mestrado, Faculdade de Ciências Médicas da Santa Casa de São Paulo.

GAGNON, John. 2006. Uma interpretação do desejo: ensaios sobre o estudo da sexualidade. Rio de Janeiro: Garamond.

GARCIA, Esteban. 2009. "Políticas e prazeres dos fluidos masculinos: barebacking, esportes de risco e terrorismo biológico". In: Maria Elvira Díaz-Benítez \& Carlos Fígari (orgs.), Prazeres dissidentes. Rio de Janeiro: Editora Garamond. pp. 537-566.
GREGORI, Maria Filomena. 2003. "Relações entre violência e erotismo". Cadernos Pagu, n. 20:87-120.

2004. "Prazer e perigo: notas sobre feminismo, sex-shops e S/M". In: Adriana Piscitelli; Maria Filomena Gregori \& Sergio Carrarra (orgs.), Sexualidades e saberes: convenções e fronteiras. Rio de Janeiro: Editora Garamond. pp. 235-256.

.2010. Prazeres perigosos: erotismo, gênero e limites da sexualidade. Tese de livre docência, Departamento de Antropologia, IFCH, Universidade Estadual de Campinas.

INGOLD, Tim. 2000. The perception of the environment: essays on livelihood, dwelling and skill. London: Routledge.

LÉVI-STRAUSS, Claude. 1989. O pensamento selvagem. Campinas: Papyrus.

LIMA, Vladimir Moreira. 2015. Deleuze-Guattari e a Ressonância Mútua entre Filosofia e Política. Ponteio Edições [https://www.facebook.com/ SeuPonto].

LOWENKRON, Laura. 2013. "Abuso sexual infantil, tráfico de pessoas e a desconstrução da centralidade do consentimento". Paper apresentado na X Reunión de Antropología del Mercosur (RAM) - Córdoba, Argentina.

MACHADO, Roberto. 2013. Deleuze, $a$ arte e a filosofia. Rio de Janeiro: Jorge Zahar Editor.

PAASONEN, Susanna. 2011. Carnal resonance. Affect and online pornography. Cambridge: The Massachusetts Institute of Technology Press.

PARKER, Richard \& TERTO JR., Veriano (orgs.). 2002. Prevenção à AIDS: limites e possibilidades na terceira década. Rio de Janeiro: ABIA.

PELÚCIO, Larissa. 2009. Abjeção e desejo: uma etnografia travesti sobre o modelo preventivo de aids. São Paulo: Anablume/Fapesp. 
PERLONGHER, Nestor. 1985. "Aids. Disciplinar os poros e as paixões". Lua Nova, São Paulo, v. 2, n. 3. . 1987. O negócio do michê: a prostituição viril. São Paulo: Editora Brasiliense.

. 1993. "Antropologia das sociedades complexas, identidade e territorialidade ou como estava vestida Margaret Mead". Revista Brasileira de Ciências Sociais, n. 22:137-144. . 2012. "Antropologia do êxtase". Revista digital Ecopolítica, n.4: 154 203. (Link: https://revistas.pucsp.br/ ecopolitica/article/view/17762/13263) Acesso em 18/04/2019.

ROCHA, Verônica Maria Monteiro da. 2011. "Ninguém se arrisca à toa: os sentidos da vida para praticantes do esporte base jump". In: Maria Claudia Coelho \& Claudia Barcellos Rezende (orgs.), Cultura e Sentimentos - ensaios em antropologia das emoções. Rio de Janeiro: Contra Capa/Faperj. pp. 63-80.

ROLNIK, Suely. 1989. Cartografia Sentimental: Transformações contemporâneas do desejo. São Paulo. Editora Clube do Livro.
RUBIN, G.S. 1998. "Thinking Sex: notes for a radical theory of the politics of sexuality". In: P.M. Nardi \& B.E. Schneider (eds.), Social perspectives in lesbian and gay studies: a reader. New York: Routledge. pp. 100-133. . 2001. "The catacombs: a temple of the butthole". In: , Deviations. Durham e London: Duke University Press. pp. 224-240.

TERTO JR., Veriano. 2002. "Homossexualidade e saúde: desafios para a terceira década de epidemia de HIV/AIDS". Horizontes Antropológicos, ano 8, n. 17:147-158.

VANCE, C. 1984. Pleasure and danger: exploring female sexuality. Nova York: Routledge.

VARGAS, Eduardo Viana. 2001. Entre a extensão e a intensidade: corporalidade, subjetivação e uso de "drogas". Tese de Doutorado, UFMG.

ZILLI, Bruno. 2009. "BDSM da A a Z: A despatologização através do consentimento nos 'manuais' da internet". In: Maria Elvira Díaz-Benítez \& Carlos Fígari, Prazeres Dissidentes. Rio de Janeiro: Garamond. pp.481-508. 
LIMITES, FISSURAS, PRAZER E RISCO EM FESTAS DE ORGIA PARA HOMENS

Resumo

Este artigo, resultado de uma pesquisa etnográfica sobre práticas sexuais coletivas entre homens, organizadas em espaços comerciais da cidade do Rio de Janeiro, busca analisar o desejo envolvido na busca de práticas em que a intensidade seja um elemento de destaque. Práticas estas em que o manejamento dos limites, o controle de si e a imersão em êxtases se apresentam como "tensores libidinais" (Perlongher 1987) e maneiras de pensar os chamados "limites da sexualidade" (Gregori 2010). Discuto aqui como essas práticas são atravessadas por questões como a violência, o consentimento, os chamados marcadores sociais de diferença, o cuidado com doenças e riscos inerentes a esses eventos, e que nesses contextos podem ser erotizados.

Palavras-chave: Prazer, Risco, Fissuras, Consentimento, Sexualidade, Intensidade.

\section{LIMITS, FISSURES, PLEASURE AND} RISK AT ORGY PARTIES FOR MEN

\section{Abstract}

This article results from ethnographic research on collective sexual practices among men, organized in commercial spaces in the city of Rio de Janeiro. It analyzes the desire involved in the search for practices in which intensity is a prominent element. Such practices, where boundary management, selfcontrol and immersion in ecstasies emerge as "libidinal tensors" (Perlongher, 1987) and ways of thinking the socalled "limits of sexuality" (Gregori, 2010). I discuss how these practices are permeated by issues such as violence, consent, so-called social markers of difference, attention to disease and the risks inherent to these events, with, in these contexts, can be eroticized.

Keywords: Pleasure, Risk, Fissures, Consent, Sexuality, Intensity. 


\title{
LÍMITES, FISURAS, PLACER Y \\ RIESGO EN FIESTAS DE ORGÍA \\ PARA HOMBRES
}

\begin{abstract}
Resumen
Este artículo es resultado de una investigación etnográfica sobre prácticas sexuales colectivas entre hombres, organizadas en espacios comerciales de la ciudad de Río de Janeiro y analiza el deseo involucrado en la búsqueda de prácticas donde la intensidad sea un elemento destacado. Prácticas donde el manejo de los límites, el control de sí y la inmersión en éxtasis se presentan como "tensores libidinales" (Perlongher, 1987) y maneras de pensar los llamados "límites de la sexualidad" (Gregori, 2010). En este sentido, se discute cómo estas prácticas se atraviesan por cuestiones como la violencia, el consentimiento, los llamados marcadores sociales de diferencia, el cuidado con enfermedades y los riesgos inherentes a esos eventos, que en este contexto pueden ser erotizadas.
\end{abstract}

Palabras clave: Placer, Riesgo, Fisura, Consentimiento, Sexualidad, Intensidad. 